\title{
Analisis Perbandingan Implementasi Metode Pembelajaran Bahasa Inggris Inovatif di Taman Kanak-Kanak
}

\author{
Maria Herdyastika ${ }^{1}$, Mozes Kuriawan ${ }^{2} \bowtie$ \\ Pendidikan Guru Pendidikan Anak Usia Dini, Universitas Kristen Satya Wacana \\ DOI: $10.31004 /$ obsesi.v5i2.902
}

\begin{abstract}
Abstrak
Pembelajaran bahasa inggris bagi anak usia dini harus menggunakan metode yang tepat agar anak dapat mempelajari banyak kosa kata dengan mudah. Tujuan dari penelitian ini untuk membandingkan metode pembelajaran Bahasa Inggris yang digunakan oleh sekolah agar dapat mengetahui metode apa yang paling tepat untuk diterapkan pada pembelajaran Bahasa Inggris bagi anak usia dini. Jenis metode penelitian yang digunakan adalah deskriptif kualitatif. Teknik pengumpulan data dalam penelitian ini adalah observasi dan wawancara. Penelitian ini di analisis menggunakan teknik analisis kekuatan dan kelemahan. Metode pembelajaran bahasa inggris yang diteliti adalah Communicative Language Teaching dan Grammar Translation. Hasil Penelitian menunjukkan bahwa metode pembelajaran bahasa inggris yang lebih efektif untuk diterapkan pada anak usia dini adalah Communicative Language Teaching. Karena metode tersebut memberikan pembiasaan setiap hari secara berulang-ulang hingga anak hafal dan mampu memahami arti kata Bahasa Inggris yang diajarkan dan bisa menjadi suatu kebiasaan. Selain itu metode tersebut dinilai cenderung lebih bermakna jika dibandingkan dengan metode Grammar Translation.
\end{abstract}

Kata Kunci:Anak Usia Dini, Metode Pembelajaran, Kosakata Bahasa Inggris.

\begin{abstract}
English education for early childhood must use the proper method so that they can easily learn many vocabulary. The aim of the study was to compare English learning methods used by schools in order to find out what methods would be most appropriate for children of an early age. The type of research methods used qualitative descriptive. The data gathering technique in this study is observation and interview. The research in analysis using strengths and weaknesses analysis. The method of English education is communicative language teaching and grammar translation. Research indicates that the more effective method of English learning is communicative language teaching. Because the method provides daily habituation until children and are able to understand the meaning of the taught English word and become a habit. Moreover, it is judged more significantly than the grammar translation method.
\end{abstract}

Keywords: Early Childhood, Learning Methods, English Vocabulary.

Copyright (c) 2020Maria Herdyastika, Mozes Kurniawan

$\triangle$ Corresponding author:

Email Address: mozeskurniawan@uksw.edu( Salatiga, Indonesia )

Received 20 November 2020, Accepted 6 December 2020, Published 12 December 2020 


\section{PENDAHULUAN}

Di Indonesia, Bahasa Inggris merupakan bahasa yang mulai banyak dipelajari dan di minati karena banyak lembaga-lembaga perusahaan menginginkan sumber daya manusia yang unggul yaitu dengan menguasai satu atau lebih bahasa asing, dan salah satu bahasa asing yang wajib dikuasai adalah Bahasa Inggris (Barnard dkk, 2002; Leonard, 2016). Di lembaga pendidikan, Bahasa Inggris juga sudah mulai berkembang. Banyak sekali sekolah yang menambahkan mata pelajaran Bahasa Inggris, salah satunya di dalam Pendidikan Anak Usia Dini (Miranti dkk, 2015; Marlianingsih, 2016; Ndraha dan Kurniawan, 2019; Qadafi, 2020). Pembelajaran bahasa Inggris tersebut mulai diajarkan dengan cara mengenal kosa kata (vocabulary), dengan cara mendengarkan (listening), berbicara (speaking), dan menulis(writing) sejak usia dini sehingga nantinya dapat menguasai banyak kosa kata Bahasa Inggris. Pembelajaran bahasa Inggris juga dapat memanfaatkan media pendukung keterampilan berbahasa seperti mainan dan kegiatan menarik seperti gerak lagu dan sejenisnya yang ada sehingga akan semakin menarik dan bermakna (Fauzia, 2016; Astutik dan Aulina, 2018; Liyana dan Kurniawan, 2019; Uzer, 2019).

Dengan menguasai bahasa global tersebut, anak-anak nantinya dapat dengan mudah berkomuniasi dengan orang lain khususnya pada tataran internasional atau kegiatan yang memerlukan bahasa Inggris sebagai bahasa pengantar. Sebagai bahasa global, Bahasa Inggris memegang fungsi dan peran yang sangat besar. Salah satu implikasi yang terlihat adalah semakin banyak orang berusaha belajar/menguasai Bahasa Inggris dengan baik karena melihat banyak sekali manfaat dari menguasai Bahasa Inggris seperti: 1) menambah pengetahuan, 2) mempermudah komunikasi dengan orang lain, 3) meningkatkan ke kepercayaan diri dengan dukungan media yang sesuai, 4) memudahkan diri untuk beradaptasi di lingkungan baru, 5) memudahkan diri untuk bergaul, dan masih banyak manfaat menguasai bahasa Inggris yang lainnya(Widyasari, 2016; Putri, 2017; Arumsari dkk, 2017; Uzer, 2019). Hal ini membuat semua orang dari berbagai kalangan termotivasi untuk mengusai Bahasa Inggris. Kecenderungan masyarakat akan penguasaan bahasa asing tersebut, membuat mereka saling berlomba memasukkan anak-anak mereka ke sekolah terbaik untuk mempelajari Bahasa Inggris sebagai salah satu keahlian yang dikembangkan. Hal ini berdasarkan asumsi bahwa anak lebih cepat belajar bahasa asing daripada orang dewasa (Santrock, 2007; Samad dan Tidore, 2015; Diniyah, 2017). Sebuah penelitian yang dilakukan Johnson dan Newport (1991) menunjukan bahwa imigran asal Cinadan Korea yang mulai tinggal di Amerika pada usia 3 sampai 7 tahun kemampuan Bahasa Inggris nya lebih baik daripada anak yang lebih tua atau orang dewasa (Santrock, 2007:313).

Dalam penelitian ini, peneliti mengindetifikasi tiga permasalahan yaitu yang diperoleh dari simpulan pengamatan dan dialog dengan pihak-pihak sekolah termasuk gejala terkini dari sumber pustaka antara lain: rendahnya tingkat penguasaan kosa kata berbahasa Inggris pada anak usia dini. Karena penguasaan kosa kata bahasa Inggris yang masih rendah, jika menerapkan metode yang kurang tepat dalam pembelajaran Bahasa Inggris bagi anak usia dini akan berpengaruh pada tingkat pemahaman dan perkembangan kemampuan berbahasanya. Kemudian, ada pula tuntutan penguasaan Bahasa Inggris di zaman yang semakin maju yang masih perlu ditingkatkan. Berdasarkan identifikasi masalah diatas maka peneliti merumuskan masalah sebagai berikut "Kerangka pembelajaran inovatif seperti apa yang relevan dengan karakteristik pembelajaran Bahasa Inggris di taman kanak-kanak?". Tujuan dari penelitian ini yaitu membandingkan metode pembelajaran Bahasa Inggris yang 
digunakan dua sekolah yaitu metode Grammar Translation atau metode Communicative Language Teaching untuk mengetahui metode manakah yang paling tepat diterapkan pada pembelajaran Bahasa Inggris bagi anak usia dini.

Menurut Cynthia \& Cahyana, (2014) kedudukan metode dalam pembelajaran mempunyai ruang lingkup sebagai cara dalam mendorong memberikan dorongan belajar. Tujuan pembelajaran dengan metode komunikatif adalah mengembangkan kompetensi siswa dalam berkomunikasi. Peningkatan komunikasi bahasa inggris siswa dapat dilihat dari kefasihan siswa dalam dalam berbicara, perbendaharaan kata yang dikuasai, dan ekspresi yang digunakan dalam berbicara bahasa inggris.

\section{METODOLOGI}

Jenis metode penelitian yang dipilih adalah deskriptif kualitatif. Penelitian kualitatif merupakan upaya untuk memperoleh data berupa deskripsi tentang hal-hal yang diamati. Basrowi dan Suwandi (2008) dalam (Ardiana dan Widiastuti, 2020) mengatakan bahwa penelitian kualitatif adalah salah satu prosedur penelitian yang menghasilkan data deskriptif berupa ucapan atau tulisan dan perilaku orang-orang yang diamati.

Dalam penelitian ini yang menjadi subjek penelitian adalah 2 sekolah Taman kanakkanak dengan metode pembelajaran Bahasa Inggris yang berbeda. Yaitu metode Grammar Translation atau metode Communicative Language Teaching. Sekolah pertama yang di ambil untuk subjek penelitian adalah KB/TK XM, Salatiga dengan jumlah siswa sebanyak 30 anak. Sekolah ini menggunakan model pembelajaran Bahasa Inggris Grammar Translation. Sekolah kedua yang diambil untuk subjek penelitian adalah KB/TK AK, Salatiga dengan jumlah siswa sebanyak 36 anak. Sekolah ini menggunakan model pembelajaran Bahasa Inggris Communicative Language Teaching.

Teknik pengumpulan data dalam penelitian ini yaitu observasi dan wawancara. Dalam penelitian ini, peneliti menggunakan observasi terstruktur dan non partisipan. Observasi terstruktur adalah observasi yang dipersiapkan tentang apa yang akan diobservasi berupa rambu-rambu pengamatan meskipun sederhana dan berkembang di lapangan. Sedangkan observasi non partisipan yaitu peneliti tidak ikut terlibat dalam kegiatan, tetapi hanya sebagai pengamat. Peneliti mengobservasi bagaimana cara guru mengajar dalam menggunakan metode pembelajaran bahasa Inggris tersebut dan bagaimana reaksi siswa di sekolah tersebut.

Wawancara, yang digunakan adalah semi wawancara dimana peneliti sudah menyiapkan pertanyaan-pertanyaan yang bisa di kembangkan untuk diajukan kepada para guru. Wawancara dilakukan kepada guru yang bersangkutan. Sekolah pertama, KB/TK XM, peneliti melakukan wawancara kepada guru yang mengampu mata pelajaran Bahasa Inggris. Sedangkan wawancara di KB/TK AK, peneliti memilih salah satu guru di sekolah tersebut untuk diwawancarai. Karena di KB/TK AK semua aktivitas menggunakan bahasa Inggris. Penelitian ini di analisis menggunakan teknik analysis kekuatan dan kelemahan. Analisis tersebut merupakan suatu teknik perencanaan strategi yang bermanfaat untuk mengevaluasi pelaksanaan pembelajaran, baik yang sedang berlangsung maupun dalam perencanaannya. Teknik analysis ini digunakan setelah data di peroleh yang berguna untuk mengetahui kekuatan, kelemahan, peluang, dan ancaman metode pembelajaran Bahasa Inggris yang digunakan dalam pengajaran di suatu Sekolah, yaitu KB/TK XM dan KB/TK AK. 


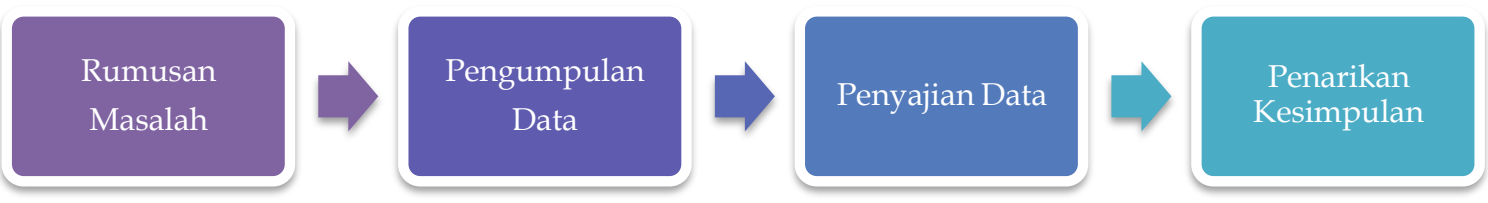

Gambar 1. Desain Penelitian

\section{HASIL DAN PEMBAHASAN}

Hasil observasi dan wawancara memberikan beberapa informasi yang berkaitan dengan metode pembelajaran bahasa Inggris Grammar Translation dan Communicative Language Teaching. Berikut ini adalah penjabaran hasil observasi dan wawancara dari masing-masing sekolah.

\section{KB/TK XM Salatiga}

Pada tanggal 24 September 2019, peneliti mengboservasi pembelajaran bahasa Inggris di kelas TK B2. Pembelajaran diawali dengan salam sapa dalam bahasa Inggris. Guru mengucapkan salam "Good morning children, how are you today?" kemudian anak akan menjawab "Im fine, thank you". Kemudian dilanjutkan ke pembelajaran, saat itu sedang mengajarkan tentang bagian-bagian rumah yaitu living room, dining room, bath room, kitchen, dan bad room. Karena banyak anak yang belum paham akhirnya Mrs.Ika menerjemahkan kepada anak-anak tentang bagian-bagaian rumah menggunakan Bahasa Indonesia secara berulang-ulang. Kemudian dilanjutkan mengerjakan worksheet, anak diberi kertas dengan gambar ruangan yang ada. Kemudian anak diinstruksikan untuk menulis (mencocokan). Karena banyak anak yang belum bisa menulis dengan tepat maka guru menuliskan bagianbagian ruangan yang ada di dalam rumah tersebut di papan tulis. Anak tinggal memilih dan mencocokan lalu di tulis di sebelah gambar. Ketika peneliti mencoba bertanya ke beberapa anak tentang bagian-bagian ruangan yang ada di dalam rumah menggunakan Bahasa Inggris, ternyata beberapa anak (hampir semua) belum memahami arti Bahasa Inggris tersebut.

Penelitian kedua di KB/TK XM Salatiga dilakukan pada tanggal 26 September 2019 di kelas A. Pada saat itu seperti biasa Mrs. Ika mengucapkan salam dan anak dapat menjawabnya menggunakan Bahasa Inggris . Pembelajaran hari itu masih tentang pemahaman konsep bagian-bagian ruangan yang ada di dalam rumah menggunakan Bahasa Inggris yaitu living room, dining room, bath room, dan bad room. Perbedaan nya di kelas B menggunakan 5 bagianbagian ruangan yang ada di dalam rumah sedangkan di kelas A hanya menggunakan 4 bagian-bagian ruangan saja (kitchen room tidak di ajarkan). Pelajaran selanjutnya adalah anak diinstruksikan untuk menebalkan garis berbentuk rumah lalu anak di perbolehkan untuk mewarnainya. Instruksi tersebut menggunakan Bahasa Indonesia. Setelah itu, pelajaran selanjutnya anak di beri instruksi untuk menulis angka 5 di buku kotan yang sudah di sediakan dan sudah di beri contoh di bagian atas buku.

Dari hasil observasi yang saya peroleh ada lebih dari dari 5 kosa kata yang di terapkan dalam pembelajaran Bahasa Inggris. Yang diajarkan selama proses pembelajaran kepada anak yaitu sesuai tema yang sedang berlangsung. Kemudian metode yang di gunakan adalah metode Grammar Translation. Dimana guru masih banyak menggunakan Bahasa Indonesia untuk menjelaskan kepada anak. Guru juga masih perlu menerjemahkan kepada anak tentang kosa kata Bahasa Inggris yang diajarkan. Pengucapan dalam pembelajaran Bahasa Inggris 
pun tidak terlalu di tekankan dan tidak ada pengulangan kata dari pembelajaran tersebut di setiap hari.

Alasan mengapa menggunakan metode tersebut karena anak belum paham tentang Bahasa Inggris, dan first language yang di gunakan adalah Bahasa Indonesia. Lalu, Kendala yang ada saat pembelajaran Bahasa Inggris yaitu guru kesulitan untuk membuat anak-anak fokus, dan kesulitan mengaitkan tema dan materi (contoh : tema = bumi, materi = batu ), membuat anak paham tentang kosa kata Bahasa Inggris yang di ajarkan juga cukup sulit, karena dirumah anak tidak diajarkan Bahasa Inggris. Walaupun ada beberapa anak yang paham tentang pelajaran Bahasa Inggris yang diajarkan. Namun rata-rata lebih banyak anak yang belum paham dengan Bahasa Inggris. Reaksi anak di dalam kelas saat pembelajaran Bahasa Inggris ada anak yang bosan karena dirumah anak sudah di ajarkan materi yang sama seperti di sekolah, ada anak yang antusias karena suka dengan pembelajaran Bahasa Inggris dan ada anak yang acuh tak acuh.

Solusi yang digunakan untuk mengatasi kendala tersebut yaitu mencari ketertarikan anak (anak suka mewarnai maka biarkan anak mewarnai), banyak mencari referensi, harus mengenali anak yang berperilaku super, dan mengetahui kemampuan anak. Cara guru menentukan tingkat ketercapaian anak yaitu ketika anak dapat mengerjakan tugas dengan baik dan betul.

Di KB/TK XM Salatiga kosakata Bahasa Inggris dilakukan hanya pada saat pembelajaran Bahasa Inggris. Pembelajaran bahasa Inggris juga dilakukan satu kali dalam seminggu. Artinya hanya menyisipkan sedikit pengajaran untuk Bahasa Inggris, dan tidak terlalu menekankan untuk pengucapan katanya dan ini sesuai dengan Metode pembelajaran Bahasa Inggris Grammar Translation. Dari hasil obsevasi, peneliti menemukan bahwa kekuatan dalam penggunaan metode Grammar Translation adalah penggunaan bahasa indonesia dalam pengajaran Bahasa Inggris di kelas lebih mudah di pahami anak. Kelemahan metode Grammar Translation sendiri hanya sedikit menyisipkan kosakata bahasa Inggris. Sehingga anak bisa jadi lupa apa yang di ajarkan di minggu sebelumnya, dan pengucapan katanya pun tidak terlalu di perhatikan walaupun kosakata Bahasa Inggris tersebut sudah di terjemahkan oleh guru yang mengajar.

Metode Grammar Translation di KB/TK XM merupakan metode yang sudah cukup baik dan tepat dilakukan karena menggunakan bahasa Ibu saat mengajarkan karena first language sendiri adalah Bahasa Indonesia jadi anak mengerti apa yang diajarkan. Tetapi, untuk pengulangan kata Bahasa Inggris sendiri masih kurang, anak mengerti apa yang di ajarkan tetapi belum memahami apa yang di ajarkan tersebut.

Peluang metode Grammar Tranlation dapat diartikan sebagai masukan yaitu sebaiknya orangtua ikut mengambil peran dengan cara saling berkomunikasi dengan guru agar tetap mengajarkan tentang tema yang sudah diajarkan saat pembelajaran Bahasa Inggis. Ancaman metode Grammar translation yaitu jika hanya di ajarkan sedikit kosakata Bahasa Inggris tanpa ada komunikasi dalam Bahasa Inggris secara berulang kemungkinan anak tidak benar-benar memahami apa yang sudah di ajarkan tersebut.

\section{KB/TK AK}

Di KB/TK AK, tidak ada guru khusus untuk pembelajaran Bahasa Inggris. Karena Bahasa Inggris di ajarkan langsung setiap hari oleh setiap guru yang mengajar ketika berkomunikasi kepada anak. Anak mendapatkan banyak kosa kata bahasa Inggris melalui 
bernyanyi, berdoa, saat mengucapkan salam dan saat berkomunikasi langsung kepada guru dan temannya. Sebagian anak yang bersekolah di KB/TK AK sudah di kenalkan Bahasa Inggris, bahkan saat berkomunikasi dengan orantuanya. Pembagian kelas dimulai dari usia yang paling kecil yaitu green apple, yellow apple, orange apple, dan red apple. Untuk green apple, yellow apple, dan orange apple, pembelajaran saat di kelas bahasa yang digunakan masih campuran yaitu bahasa pertama Bahasa Indonesia dan bahasa kedua atau Bahasa Inggris . Ke tingkat paling tinggi yaitu red apple, saat pembelajaran di kelas bahasa yang digunakan sudah sepenuhnya menggunakan Bahasa Inggris.

Dari hasil observasi yang peneliti peroleh Di KB/TK AK, ada banyak kosa kata yang di ajarkan oleh guru kepada muridnya (lebih dari 40 kosakata per hari). Metode yang di gunakan adalah Communicative Language Teaching. Karena setiap hari anak mendapatkan kosa kata baru Bahasa Inggris dan dilakukan secara berulang saat berkomunikasi kepada guru maupun teman-temannya. Pengucapan kosa kata berbahasa Inggris pun sangat di tekankan terbukti saat anak salah mengucapkan kata berbahasa Inggris, guru akan memperbaikinya secara berulang dan menanyakan nya beberapa kali. Respon anak saat pengajaran Bahasa Inggris, ada beberapa anak yang paham kerena memang di rumah sudah diajarkan dan bahasa yang di gunakan sehari-hari adalah Bahasa Inggris. Namun ada beberapa anak yang belum paham karena bahasa yang di gunakan sehari-hari saat berada di rumah menggunakan Bahasa Indonesia atau Bahasa Jawa.

Yang diajarkan selama proses pembelajaran adalah yang pertama greeting, lalu karakter building yaitu 5 magic word (sorry, help, excuse me, please, and thank you) dan yang terakhir pembelajaran yang di lakukan harus sesuai tema. Alasan mengapa menggunakan metode Communicative Language Teaching karena sekolah tersebut menggunakan kurikulum nasional plus (kurikulum dari dinas tetapi di kembangkan yaitu penambahan Bahasa Inggris saat berkomunikasi maupun saat pembelajaran).

Kendala saat pembelajaran pengenalan Bahasa Inggris kepada anak yaitu ada yang basicnya 0 yaitu anak yang menggunakan Bahasa Indonesia - Jawa dan dari parents karena tidak bisa menguasai Bahasa Inggris. Alternative solusi untuk menyikapi kendala tersebut dengan cara mengkomunikasikan langsung ke parents dan pemberian weekly schedule (jadwal seminggu kedepan) yang di harapkan agar parents dapat mengajarkan dahulu sebelum pembelajaran di sekolah. Cara guru menentukan tingkat pemahaman ketercapaian siswa dalam Berbahasa Inggris yaitu dengan cara pembagian report saat tengah semester dan akhir semester. Sudah ada standart sendiri dalam penilaian. Penilaian diberikan melalui narrative text pada setiap anak. Reaksi siswa saat berada di dalam kelas ada yang langsung merespon, ada yang harus di translate terlebih dahulu.

Di sekolah KB/TK AK, kosa kata Bahasa Inggris di dapatkan anak setiap hari saat berkomunikasi kepada guru, memberi salam, berdoa, dan bernyanyi. Penguasaan kosakata Bahasa Inggris dilakukan secara berulang, dan guru membenarkan anak ketika salah saat pengucapan kosa kata Bahasa Inggris tersebut. Kosa kata dan pengajaran Bahasa Inggris yang di dapatkan anak, di teruskan saat anak berkomunikasi kepada teman lainnya contohnya ketika guru selalu mengingatkan jika berbuat salah harus mengatakan "Sorry", anak dapat mencontoh gurunya walaupun harus laporan terlebih dahulu "Miss, A ndak say sorry sama $a k u$ ". Atau anak lagsung mengatakan sorry ketika ia berbuat salah.

Hal ini sesuai dengan beberapa ciri Metode pembelajaran Bahasa Inggris Communicative Language Teaching. Kekuatan dalam metode Communicative Language 
Teachingdi KB/TK AK adalah di mana anak banyak diajak beinteraksi dengan komunikasi menggunakan Bahasa Inggris secara berulang sehingga menjadi kebiasaan hingga anak benarbenar memahami arti dari kosa kata tersebut. Kelemahan dari metode Communicative Language Teaching sendiri jika ada anak dari basic atau latar belakang menggunakan first language Bahasa Inggris dan anak tersebut hanya mampu memahami ketika seseorang berkomunikasi dengan Bahasa Inggris padahal tidak semua anak yang bersekolah di KB/TK AK memiliki basic yang sama. Jadi, ketika berkomunikasi anak tersebut tidak memahami apa yang di katakan temannya dan guru harus menterjemahkannya terlebih dahulu.

Metode Communicative Language Teaching sudah baik dalam pengajarannya di KB/TK AK. Pengulangan kosakata Bahasa Inggris setiap hari mulai saat Toodler hingga TK B membuat anak mampu memahami arti kosa kata Bahasa Inggris tersebut. Para guru juga tidak segan untuk membenarkan pengucapan kata yang salah ketika anak salah mengucapkan kosa kata Bahasa Inggris yang sedang di ajarkan tersebut walaupun masih kurang dalam pendekatan kepada anak yang benar-benar belum memahami arti kosa kata Bahasa Inggris

Peluang dari metode Communicative Language Teaching anak memiliki banyak kosa kata Bahasa Inggris dengan metode ini tetapi anak dari latar belakang menggunakan Bahasa Indonesia atau bahkan Bahasa Jawa akan lebih baik ketika guru lebih melakukan pendekatan kepada anak tersebut sehingga anak bukan hanya mengerti tapi juga memahami arti Bahasa Inggris tersebut. Ancaman dari metode Communicative Language Teaching ketika anak mampu menguasai Bahasa Inggris di sekolah tetapi saat berada di rumah dan berkomunikasi kepada orangtua, orangtua tidak memahami apa yang sedang di komunikasikan anak.

Berdasarkan hasil penelitian maka dapat disimpulkan bahwa metode pembelajaran yang lebih efektif untuk digunakan pada pembelajaran bahasa inggris anak usia dini adalah metode communicative language teaching. Metode ini dinilai lebih bermakna dibandingkan metode grammar translation. Karena metode ini kurang kontekstual jika dikaitkan dengan karakteristik pembelajaran anak usia dini. Hal ini sama dengan yang dikatakan oleh Cynthia dan Cahyana, (2014) bahwa metode communicative language teaching memiliki efektivitas yang cukup tinggi dalam meningkatkan kemampuan komunikasi berbahasa inggris siswa. Dalam penelitian Kustini, (2019) juga mengatakan bahwa keaktifan berbahasa inggris dapat ditingkatkan dengan metode communicative language teaching. Hal serupa juga dikatakan oleh Richards, (2006) bahwa penggunaan metode communicative language teaching dapat memberikan pembelajaran bahasa inggris yang lebih bermakna bagi siswa.

\section{SIMPULAN}

Berdasarkan data yang diperoleh, dapat di simpulkan bahwa metode Communicative Language Teaching lebih efektif dalam pengajaran Bahasa Inggris kepada anak. Hal tersebut karena adanya pembiasaan setiap hari secara berulang hingga anak hafal dan mampu memahami arti kata Bahasa Inggris sebagai suatu kebiasaan. Maka, saran untuk pihak sekolah yang ingin mengimplementasikan pembelajaran bahasa Inggris di jenjang PAUD / TK, agar semua pihak dilibatkan serta mengambil peran seperti kepala sekolah yang mengarahkan pendekatan pembelajaran, guru mengembangkan konten dan kegiatan belajar bahasa Inggris sesuai karakteristik anak dan pengembangan pendekatan pembelajaran bahasa Inggris yang terus dikembangkan akan berpeluang meningkatkan perkembangan penguasaan bahasa asing tersebut.

\section{UCAPAN TERIMAKASIH}


Saya ucapkan terima kasih kepada pihak sekolah yang telah mengizinkan saya untuk melaksanakan penelitian. Penelitian ini tidak dapat berjalan dengan lancar tanpa dukungan pihak sekolah.

\section{DAFTAR PUSTAKA}

Ardiana, D. N., \& Widiastuti, A. A. (2020). Penerapan Pendekatan BCCT di KB-TK Realfunrainbow Preschool Salatiga. Jurnal Obsesi: Jurnal Pendidikan Anak Usia Dini. https:// doi.org/10.31004/obsesi.v5i1.707

Arumsari, A. D., Arifin, B., \& Rusnalasari, Z. D. (2017). Pembelajaran Bahasa Inggris pada Anak Usia Dini di Kec Sukolilo Surabaya. Jurnal PG-PAUD Trunojoyo : Jurnal Pendidikan Dan Pembelajaran Anak Usia Dini, 4(2), 133. https:// doi.org/10.21107/jpgpaud.v4i2.3575

Astutik, Y., \& Aulina, C. N. (2018). Metode Total Physical Response (TPR) Pada Pengajaran Bahasa Inggris Siswa Taman Kanak-Kanak. Jurnal Pendidikan Bahasa Dan Sastra, 17(2), 200. https://doi.org/10.17509/bs_jpbsp.v17i2.9658

Barnard, R., Richards, J. C., \& Rodgers, T. S. (2002). Approaches and Methods in Language Teaching. TESOL Quarterly, 36(4), 636. https://doi.org/10.2307/3588247

Cynthia, A. R., \& Cahyana, A. (2014). Efektivitas Metode Communicative Language Teaching (CLT) Dalam Meningkatkan Kemampuan Komunikasi Berbahasa Inggris Peserta Kursus Di PQEC Institute. Jurnal Pendidikan Luar Sekolah, 10(2).

Diniyah, F. (2017). Persepsi Orang Tua dan Guru Mengenai Bahasa Inggris pada Anak Usia Dini di TK ABA Karangmalang Yogyakarta. Jurnal Tarbiyah: Jurnal Ilmiah Kependidikan, 6(2). https://doi.org/10.18592/tarbiyah.v6i2.1594

Fauzia, F. (2016). Metode TPR (Total Physical Response) Sebagai Alternatif Untuk Meningkatkan Kemampuan Tahap Awal Berbahasa Inggris Pada Anak-Anak. Jurnal Penelitian Ilmu Pendidikan, 9(1). https:/ / doi.org/10.21831/jpipfip.v9i1.10687

Kustini, T. (2019). Pendekatan Communicative Language Teaching Dalam Video Project Youtube Untuk Meningkatkan Motivasi Belajar Siswa. Jurnal Educatio FKIP UNMA, 5(1), 12-18. https://doi.org/10.31949/educatio.v5i1.9

Leonard, L. (2016). Kompetensi Tenaga Pendidik di Indonesia: Analisis Dampak Rendahnya Kualitas SDM Guru dan Solusi Perbaikannya. Formatif: Jurnal Ilmiah Pendidikan MIPA, 5(3). https:// doi.org/10.30998/formatif.v5i3.643

Liyana, A., \& Kurniawan, M. (2019). Speaking Pyramid sebagai Media Pembelajaran Kosa Kata Bahasa Inggris Anak Usia 5-6 Tahun. Jurnal Obsesi : Jurnal Pendidikan Anak Usia Dini, 3(1), 225. https:// doi.org/10.31004/obsesi.v3i1.178

Marlianingsih, N. (2016). Pengenalan Kosa Kata Bahasa Inggris Melalui Media Audio Visual ( Animasi ) Pada PAUD. Faktor Jurnal Ilmiah Kependidikan, 3(2). https:// doi.org/10.30998/.v3i2.782

Miranti, I., Engliana, \& Hapsari, F. S. (2015). Penggunaan Media Lagu Anak-Anak Dalam Mengembangkan Kemampuan Kosakata Bahasa Inggris Siswa Di PAUD. Jurnal Ilmiah Kependidikan, 2(2), 167-173. https:// doi.org/10.30998/.v2i2.382

Ndraha, V. E., \& Kurniawan, M. (2019). Playing “CABE" (Searching and Whispering) to Increase Children's English Vocabulary. JPUD - Jurnal Pendidikan Usia Dini, 13(1), 143157. https:/ / doi.org/10.21009/10.21009/JPUD.131.11

Putri, A. R. (2017). Pengembangan materi bahasa inggris untuk anak usia dini di paud pelangi guyangan. Jurnal Linguistiks Terapan Dan Pendidikan Bahasa, 4(1). https:// doi.org/10.34001/edulingua.v4i1.551

Qadafi, M. (2020). Pembelajaran Bahasa Inggris pada Anak di Sangkhom Islam Wittaya School saat Pandemi Covid-19. Jurnal Obsesi: Jurnal Pendidikan Anak Usia Dini, 5(1), 422. https:// doi.org/10.31004/obsesi.v5i1.591

Richards, J. (2006). Communicative Language Teaching Today. In Cambridge University Press. Samad, F., \& Tidore, N. (2015). Strategi Pembelajaran Bahasa Inggris Yang Menyenangkan 
Untuk Anak Usia Dini. Cahaya PAUD.

Santrock, J. W. (2007). Perkembangan ANak. Jakarta: Erlangga.

Uzer, Y. (2019). Implementasi Pembelajaran Bahasa Inggris Anak Melalui Metode Gerak Dan Lagu Untuk Anak PAUD. PERNIK: Jurnal Pendidikan Anak Usia Dini, 2(01), 96. https://doi.org/10.31851/pernik.v2i01.3117

Uzer, Y. V. (2019). Strategi Belajar Bahasa Inggris Yang Menyenangkan Untuk Pendidikan Anak Usia Dini. PERNIK: Jurnal Pendidikan Anak Usia Dini, 2(01), 86. https://doi.org/10.31851/pernik.v2i01.3116

Widyasari, F. E. (2016). Pembelajaran Bahasa Inggris dengan Menggunakan Metode Multiple Intelligences: Studi Kasus di Sekolah Internasional. Jurnal Edutama, 3(1), 31-46. https://doi.org/10.30734/jpe.v3i1.29 